\title{
Erratum to: Genome-wide transcriptional and physiological responses to drought stress in leaves and roots of two willow genotypes
}

Pascal Pucholt ${ }^{1}$, Per Sjödin ${ }^{1,2}$, Martin Weih ${ }^{3}$, Ann Christin Rönnberg-Wästljung ${ }^{1}$ and Sofia Berlin ${ }^{1 *}$

\section{Erratum}

Following publication of this work [1] it was noticed that an incorrect version of Fig. 1 was published. The figure contained 18 panels from A-U. However panel J was not listed and this should have read A-T. The correct version of Fig. 1 has been corrected in the original article and is also included correctly below. The publisher apologizes for any inconvenience caused.

\footnotetext{
Author details

'Department of Plant Biology, Uppsala BioCenter, Linnean Centre for Plant Biology, Swedish University of Agricultural Sciences, Uppsala SE-750 07, Sweden. ${ }^{2}$ Department of Evolutionary Biology, Evolutionary Biology Centre, Uppsala University, Uppsala SE-752 36, Sweden. ${ }^{3}$ Department of Crop Production Ecology, Linnean Center for Plant Biology, Swedish University of Agricultural Sciences, Uppsala SE-750 07, Sweden.
}

Received: 14 October 2015 Accepted: 2 November 2015

Published online: 03 December 2015

\section{Reference}

1. Pucholt P, Sjödin P, Weih M, Rönnberg-Wästljung AC, Berlin S. Genome-wide transcriptional and physiological responses to drought stress in leaves and roots of two willow genotypes. BMC Plant Biology. 2015;15:244.

\footnotetext{
* Correspondence: sofia.berlin@slu.se

'Department of Plant Biology, Uppsala BioCenter, Linnean Centre for Plant Biology, Swedish University of Agricultural Sciences, Uppsala SE-750 07, Sweden

Full list of author information is available at the end of the article

\section{Submit your next manuscript to BioMed Central} and take full advantage of:

- Convenient online submission

- Thorough peer review

- No space constraints or color figure charges

- Immediate publication on acceptance

- Inclusion in PubMed, CAS, Scopus and Google Scholar

- Research which is freely available for redistribution

Submit your manuscript at www.biomedcentral.com/submit 


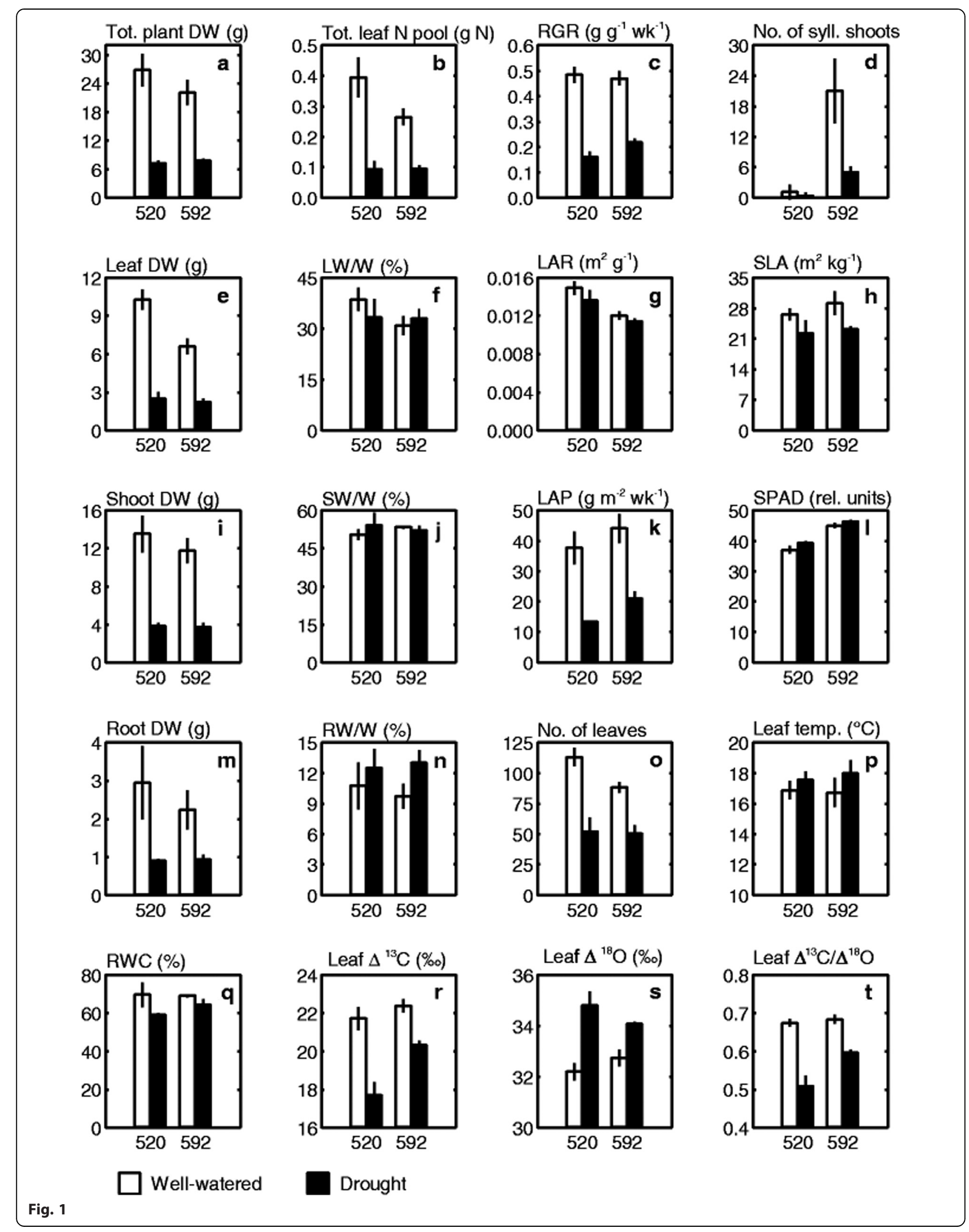

